\title{
Mary Fairfax Somerville, Queen of Science
}

\author{
by Elisabetta Strickland
}

On November 29, 1872, when Mary Fairfax Somerville passed away in Naples at the remarkable age of ninety-two, an obituary notice appeared in London's Morning Post, which described her as the "Queen of Nineteenth-Century Science."

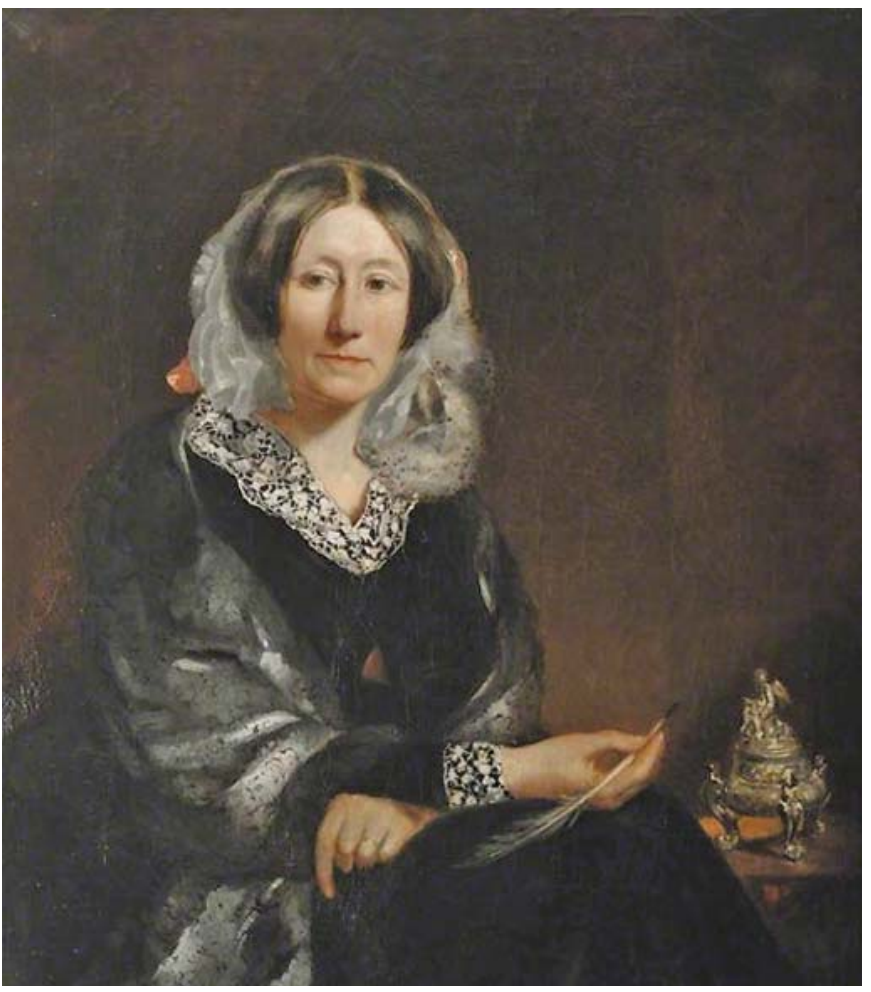

Figure 1. When she died in 1872, Mary Somerville was hailed by London's The Morning Post as the "Queen of Nineteenth-Century Science."

Elisabetta Strickland is professor of algebra at Università di RomaTor Vergata. Her e-mail address is strick1a@mat . uni roma2. it For permission to reprint this article, please contact: reprint-permission@ams.org.

DOI: http://dx.doi.org/10.1090/noti 1569
In September of this year The Royal Bank of Scotland will issue the new ten-pound plastic banknote (see Figure 2) featuring an image of Mary Somerville, an honor that up to now has been reserved for the queen of England. Somerville garnered 4,100 votes on Facebook, with much of her support coming from students of Somerville College, Oxford University, UK. Her extraordinary mathematical talent came to light through fortuitous circumstances, so it's interesting to trace the story of her life and her work.

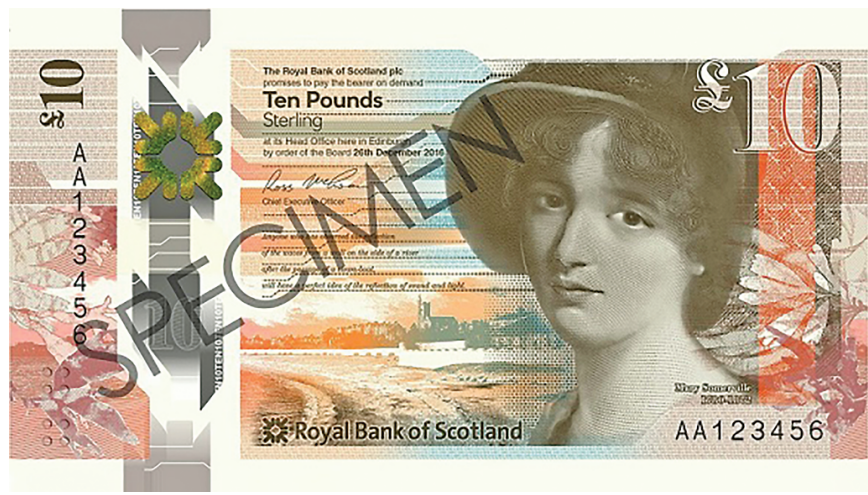

Figure 2. In September 2017 the Royal Bank of Scotland will feature Mary Somerville on the new ten-pound banknote.

Her success as a scientist and as a writer was possible because of her persistence in pursuing the study of mathematics and astronomy despite the limited range of her formal education due to prejudices about women's fitness for academic training.

As a young girl, Mary Fairfax, born in Jedburgh, Scotland, in 1780, was by her own admission a "wild creature," barely taught to read and write. Her father, a vice admiral of the British Navy, was away from home for long periods. Her mother didn't care much for Mary's education, so she only taught her to read the Bible and do tasks reserved for the women of the household, such as caring for the 
poultry and the dairy, tasks that didn't occupy her whole day. She had plenty of time to roam the countryside and seashore near her home in Burntisland, on the Fifeshire coast, collecting shells, observing the animals she encountered, and especially studying the habits of the birds, her favorite living creatures. Her carefree existence came to an end when her father returned from a long voyage and found out that Mary's reading and writing skills were minimal to nonexistent. So she was sent to a school run by a certain Miss Primrose, whose teaching methods were close to torture. After one year of continuous tears, Mary returned home to her wandering existence. But at least she could now read the few books in her family's library, starting with Shakespeare.

When she was thirteen, her interest in mathematics burst out, thanks to a fortunate encounter. During a party she was paging through a fashion magazine and came across a puzzle. The answer showed $x$ 's and y's in the solution. She asked a friend about the meaning of those symbols. She was told that it was something called algebra. Mary asked her brother's tutor, who lent her Bonnycastle's Introduction to Algebra. When her mother sent her to Edinburgh for painting lessons, she managed to obtain Euclid's Elements of Geometry, which according to the master of the school was very important to understand perspective and mechanical science. She studied at night when the rest of the household was asleep. Her unusual nocturnal habit was discovered by her mother, as the candle supply was dangerously decreasing. The family thought that it would be better if she got married. They introduced her to a cousin, Samuel Greig, an officer in the navy, and in 1804 he became her husband. Her marriage was unhappy. Greig didn't tolerate her scientific interests, and she had little time to cultivate her intellectual needs, as she had to take care of the household and two children. In 1807, after only three years of marriage, Greig died, leaving her with a small inheritance.

Mary returned to her parents' house, where she collected a small library of books of mathematics suggested by Professor William Wallace of the University of Edinburgh, with whom she became acquainted after solving a prize problem on Diophantine equations, for which she was awarded a silver medal cast in her name. The list included Pierre Laplace's Mécanique Céleste, so she first taught herself French in order to understand its contents. Then she went through the entire library, learning differential calculus from Lagrange and studying Newton's Principia. At night she gazed at the stars in the sky from the window of her room, convinced that there were deep rules governing the universe, which she had to understand and master. Her family at that point was more worried than ever and believed that her lifestyle was foolish, so they organized a second marriage to another cousin, Dr. William Somerville, inspector of the Army Medical Board.
This husband was completely different from the first one. He was handsome and cultured, with refined manners. He encouraged Mary's interests, helping her in finding the books, reading her proofs, checking her manuscripts, and introducing her to scientists and mathematicians. He took her to visit William Herschel, the celebrated astronomer, who was carrying out sky surveys with the help of a large telescope he had built with his sister, Caroline, the first woman to discover a comet, and his son, John, who became a lifelong friend of Mary's.

Mary also became acquainted with Charles Babbage, who was working on his analytical machine with the help of Ada Lovelace, daughter of Lord Byron; Michael Faraday; and Adam Sedgwick, one of the founders of modern geology, who invited her to Trinity College, Cambridge. Sir Edward Parry, a leading astronomer, named a small island in the Arctic after her.

Mary's interaction with the British intelligentsia was fruitful, as she published in 1826 a paper in the Philosophical Transactions of the Royal Society entitled "On the magnetizing power of the more refrangible solar rays," after which she became, with Caroline Herschel, one of the first two women to be appointed honorary members of the Royal Astronomical Society. The Royal Society commissioned the leading English sculptor Francis Leggatt Chantrey to carve a bust of Mary.

These events attracted the attention of Sir Lord Brougham, who had founded the Society for the Diffusion of Useful Knowledge, intended to produce affordable and readable texts on scientific topics for an increasingly literate and educated population. He commissioned her to write a popular translation of Laplace's Mécanique Céleste, which she produced in three years of hard work. The work included a Preliminary Dissertation, published independently, intended to help readers in the understanding of Laplace's work; it soon became a major statement on the intellectual power of science. Laplace himself had met Mary in Paris during one of her visits and had praised her for her deep understanding of his work.

Mary was commissioned by Lord Brougham to write three other important treatises: On the Connection of the Physical Sciences in 1846, Physical Geography in 1848, and On the Molecular and Microscopic Science in 1869. In the first she conjectured that the perturbations of the orbit of Uranus might result from an unknown planet, thus anticipating the discovery of Neptune.

Mary Somerville's scientific writings earned her the respect of the scientific community in Britain and France, a Victoria gold medal of the Royal Geographical Society, and a civil pension of 200 pounds a year, to which the prime minister Lord John Russell added 100 pounds a year, allowing Mary to be free from financial problems. Unluckily her husband got an infectious disease, which required a 
warmer climate. So they moved to Italy, where she spent thirty years of a nomadic life, falling in love with all the cities she visited: Rome, Florence, Venice, Siena, Perugia, Turin, Genoa, La Spezia, and finally Naples. Even when her husband died in 1860, she preferred to remain in Italy, where she became acquainted with many of the scientists of that time, such as Baron Giovanni Plana in Turin, known for the Abel-Plana formula in analysis; Padre Francesco De Vico, director of the Observatory of the Collegio Romano; and Annibale De Gasparis, who was in charge of the Observatory of Capodimonte in Naples and had discovered nine asteroids. She became friends with many illustrious intellectuals and politicians: the Grand Duke of Tuscany, Leopoldo II, who allowed Mary to use the library of the Pitti Palace in Florence and enjoyed explaining to the clever Scottish lady his work for the drainage of the Tuscan marshes; Don Michelangelo Caetani, Duke of Sermoneta, whom she visited often in Rome in his beautiful palazzo, meeting point of artists and writers; the poets Elizabeth and Robert Browning, who lived in Florence for the same health reasons as her husband; and the politicians Camillo Cavour in Turin and Bettino Ricasoli in Florence, thanks to whom she could witness the unification of Italy after the War of Independence.

After the death of her husband in 1860, her grief was so strong that she left Florence and moved first to La Spezia and then to Naples, together with her daughters, Martha and Marie Charlotte. She had lost two children to infectious diseases, which the medicines of those times couldn't cure. A son, Woronzow, living in England as a barrister-at-law, corresponded with his mother throughout his life; their beautiful letters are kept in the Somerville Collection at the Bodleian Library of the University of Oxford. Mary was more than eighty years old when she settled in Naples, but she was in good health except for shaking hands

\section{Mary's legacy is powerful proof of what a woman can do.} and hearing difficulties. Her fourth book, On the Molecular and Microscopic Sciences, was published when she was eighty-nine years old. In her very last years she wrote her autobiography, Personal Recollections, which she left to her daughters in handwritten form, as John Herschel had advised her to wait until after her death to publish it. In November 1872 she peacefully passed away in her sleep, having spent her last evening studying the quaternions, a number system that extends the complex numbers. She had written that she regretted not having concentrated only on mathematics and astronomy.

Mary's legacy of excellently written scientific books is powerful proof of what a woman can do. She wrote that it was "unjust that women should have been given a desire for knowledge if it were wrong to acquire it."

\section{Image Credits}

Figure 1 courtesy of Somerville College Archives. Figure 2 courtesy of Royal Bank of Scotland.

Author headshot by Martina Lanini.

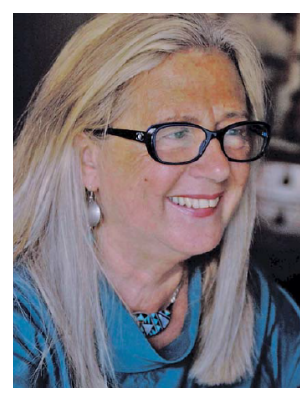

Elisabetta Strickland

\section{ABOUT THE AUTHOR}

Elisabetta Strickland is president of the central committee for the promotion of equal opportunities, workers' welfare, and nondiscrimination at the University of Rome Tor Vergata. Last year she published a biography of Somerville, The Ascent of Mary Somerville in 19th Century Society, with Springer.

\section{Twenty Years Ago in the Notices}

\section{September 1997:}

Mathematics Journals Should Be Electronic and Free, by Steven G. Krantz

The electronic revolution that is unfolding today in mathematics publishing was just getting started when this article appeared in 1997. Mathematicians were writing their own papers with TeX and making them available electronically to their colleagues. In this new world, it seemed likely that traditional journals - paid for by subscriptions, printed on paper, and stored in libraries - would become a thing of the past. The author discusses some of the drawbacks of losing the traditional journal model.

www. ams.org/notices/199708/page2.pdf 